Mongolian Geoscientist

Original article

\title{
Stratigraphy of the Khuvsgul Group, Mongolia
}

\author{
Eliel Anttila ${ }^{1 *}$ (iD) Francis Macdonald $^{1}$ (iD) Uyanga Bold $^{2}$ (iD
}

\author{
${ }^{I}$ Department of Earth Science, University of California Santa Barbara, CA, 93106, USA \\ ${ }^{2}$ Department of Research and Cooperation, Mongolian University of Science and Technology, Ulaanbaatar 14191, Mongolia \\ *Corresponding author: eanttila@ucsb.edu, ORCID: 0000-0002-7563-2710
}

\section{ARTICLE INFO}

\section{Article history:}

Received 1 March, 2021

Accepted 20 June, 2021

\begin{abstract}
The Khuvsgul Group (Khuvsgul Province, Mongolia) is a Late Neoproterozoic to Cambrian carbonate-dominated succession that includes minor glacial diamictite and one of the largest known ore-grade phosphate deposits in the world. These strata, which have experienced low-grade metamorphism, are exposed in the KhoridolSaridag Range on the western margin of Lake Khuvsgul. Since 2017, new geologic mapping and field studies have been conducted in the Khuvsgul region. During the course of this work, it has become necessary to restructure the stratigraphic framework of the Khuvsgul Group in order to better facilitate geologic mapping, stratigraphic observations, and regional correlations. We have divided the lower Khuvsgul Group into four distinct formations spanning the Cryogenian and Ediacaran, each of which encompass strata associated with the Sturtian glaciation, Cryogenian non-glacial interlude, Marinoan glaciation, and basal Ediacaran transgression respectively. The phosphorites of the Khuvsgul Group are now included within a new distinct formation, while the overlying Cambrian carbonates and siliciclastic rocks have been further subdivided to streamline mapping and correlation efforts. The stratigraphic framework outlined below will simplify identification and differentiation of Khuvsgul Group rocks in the field and provide a foundation for the interpretation of Khuvsgul Group strata within the context of the changing climatic, tectonic, and paleoenvironmental conditions of the late Neoproterozoic and early Cambrian.
\end{abstract}

Keywords: sedimentology, phosphorite, Cryogenian, Ediacaran, Cambrian, CAOB.

\section{INTRODUCTION}

Located on the northern Tuva-Mongolia terranes (Ilyin, 1971; Kuzmichev, 2015; Bold et al., 2019), and exposed in a north-south belt along the ridgelines above the west shores of Lake Khuvsgul (Figs 1 and 2), the Khuvsgul Basin hosts the late Neoproterozoic to Cambrian Khuvsgul Group (Ilyin and Ratnikova, 1981;
Macdonald and Jones, 2011). The Khuvsgul Group is a $\sim 3 \mathrm{~km}$-thick succession composed predominantly of limestone and dolomite, with minor diamictite, phosphorite, and siliciclastic rocks. Early geological investigation of the Khuvsgul Group centered around the ore-grade Khuvsgul phosphorite (Ilyin, 1973; Ilyin and Ratnikova, 1981). More recent work has focused

(C) The Author(s). 2021 Open access This article is distributed under the terms of the Creative Commons Attribution 4.0 International License (https://creativecommons.org/licenses/by/4.0/), which permits unrestricted use, distribution, and reproduction in any medium, provided you give appropriate credit to the original author(s) and source, provide a link to the Creative Commons license, and indicate if changes were made. 
on Cryogenian Snowball Earth glaciations recorded by the diamictite units (Macdonald and Jones, 2011) and the late Ediacaran to Cambrian Doushantuo-Pertatanka-type microfossil assemblage within the phosphatic strata (Anderson et al., 2017; 2019). Over the past half-century, workers have developed a variety of stratigraphic schemes for the Khuvsgul Group, with correlations to putatively equivalent units on the Siberian side of the RussianMongolian border (Osokin and Tyzhinov, 1998; Kuzmichev et al., 2001; Vishnevskaya and Letnikova, 2013), or the southwest margin of the Zavkhan terrane (Macdonald and Jones, 2011, Smith et al., 2016, Bold et al., 2016a,b). Stratigraphic frameworks proposed by previous workers are summarized in Fig. 3. Here we propose an updated stratigraphic framework based on new geological mapping, lithostratigraphic observations, and biostratigraphic constraints (see Figs 2, 3, 4, and 5).

Based on the regional basinal stratigraphic divisions outlined by Macdonald and Jones (2011), our new stratigraphy further divides map units on the basis of discrete lithostratigraphic trends observed throughout the Khuvsgul paleobasin. First, we propose that the Ongolog Formation, which includes diamictite and carbonate, be separated into the Ongolog Formation (glacial facies) and Bakh Formation (non-glacial facies). The Bakh Formation is further subdivided, based on basinallyconsistent lithological changes, into the Khurts, Bumbulug, and Salkhitai members. Next, strata formerly incorporated into the Kheseen Formation (Macdonald and Jones, 2011) are subdivided: the newly defined Shar Formation includes a diamictite and breccia sequence, while a cap carbonate and overlying

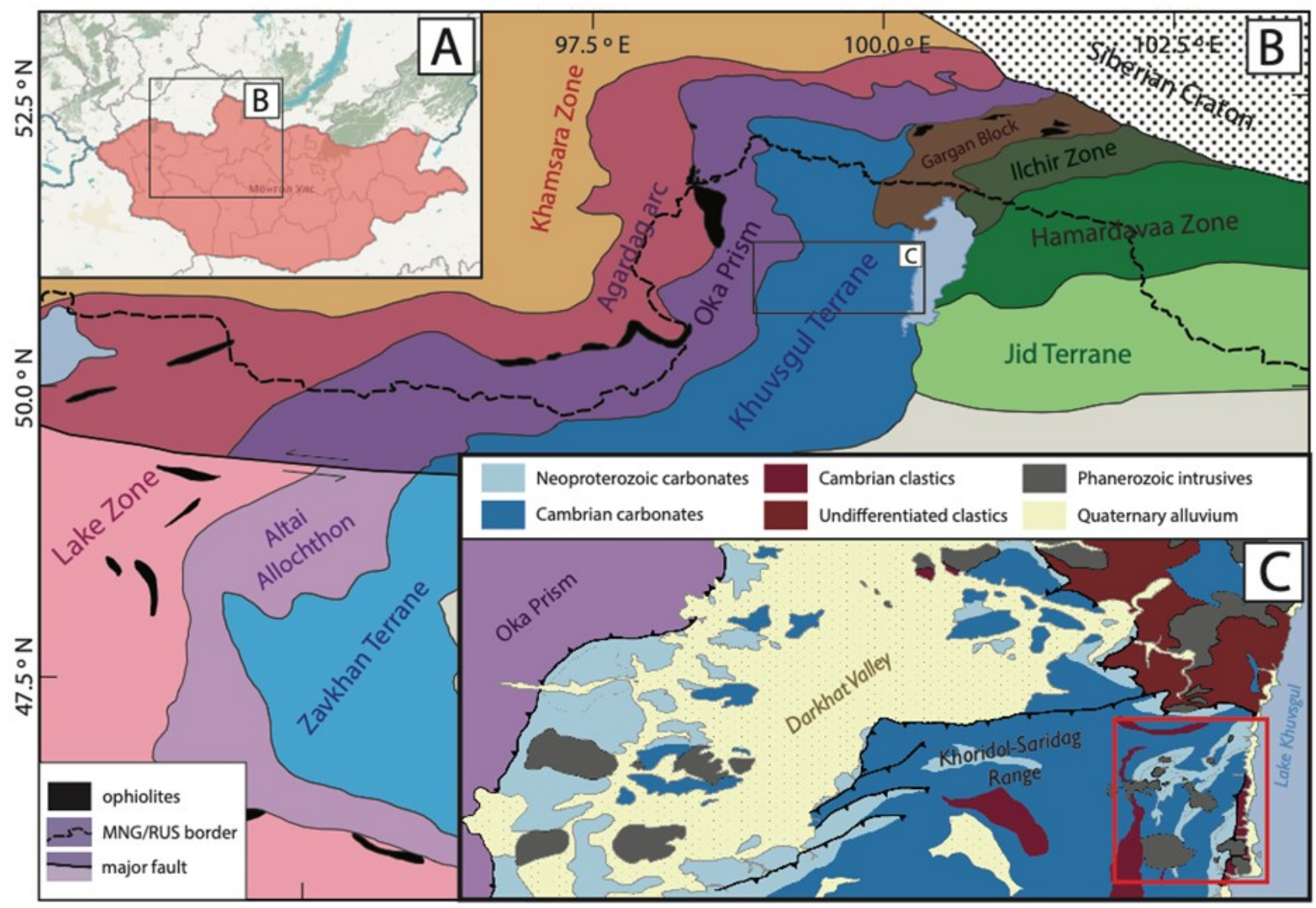

Fig. 1. Location and geologic context of northern Mongolia. A: Geopolitical map of northern Mongolia. B: Tectonic map of the northern Mongolian portion of the Central Asian Orogenic Belt, modified from Bold et al. (2016b, 2019) and Kuzmichev (2015). C: Generalized geologic map of the Khoridol-Saridag Range and Darkhat Valley. A detailed geologic map of the area outlined in red is shown in Fig. 2. 


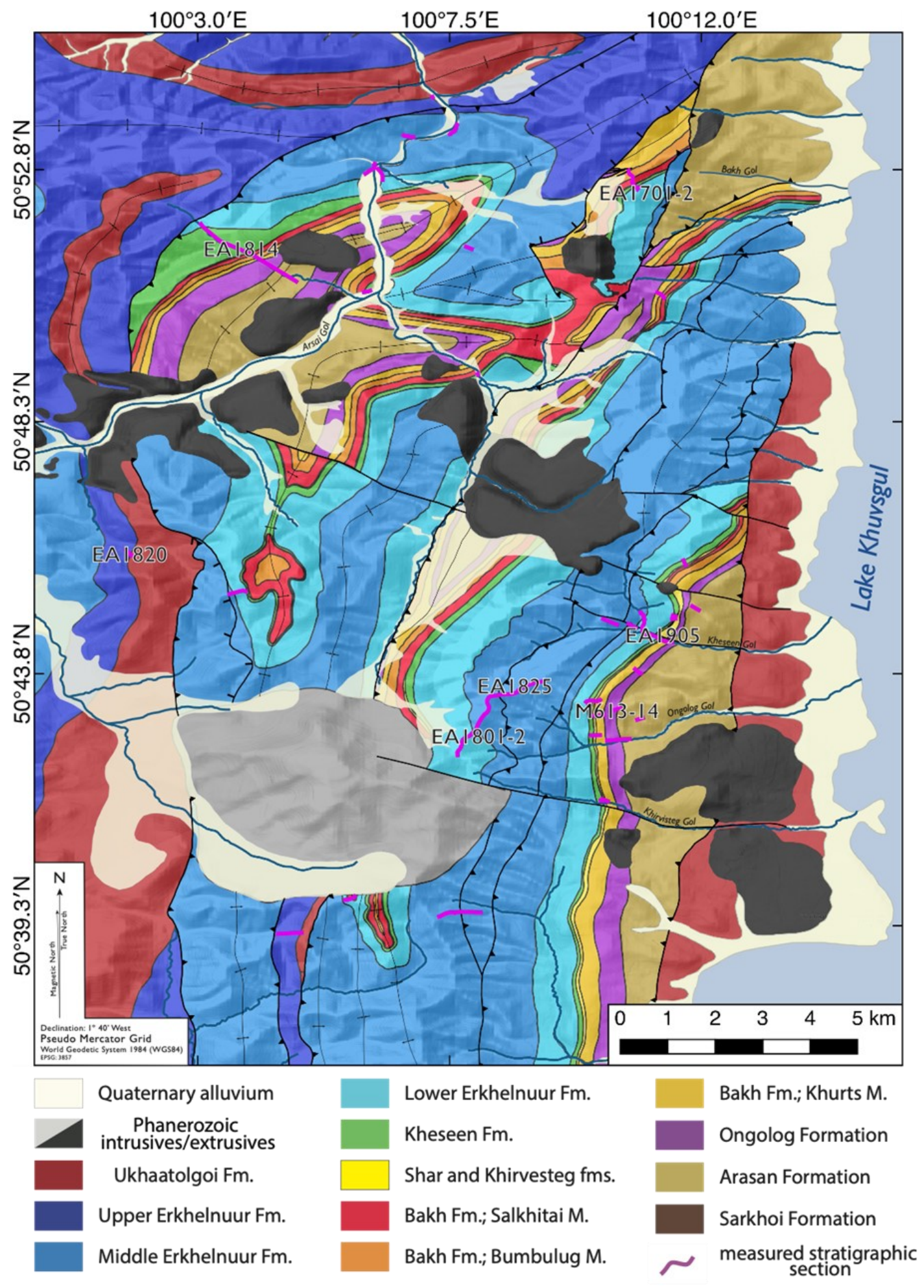

$$
\text { thrust fault normal fault } / \text { strike-slip fault } X \text { syncline axis } X \text { anticline axis }
$$

Fig. 2. Geologic map of the eastern and central Khoridol-Saridag Range, Khuvsgul Aimag, Mongolia. Locations of measured stratigraphic sections are depicted with lavender lines. Only type-locality measured sections are labeled, as are river drainages or gorges ("gols") relevant to locations discussed in this work. Note that the Shar Formation and Khirvesteg Formation are depicted in this figure as a single unit, as the Khirvisteg Formation is generally too thin to be clearly discernible at the map scale presented here. 


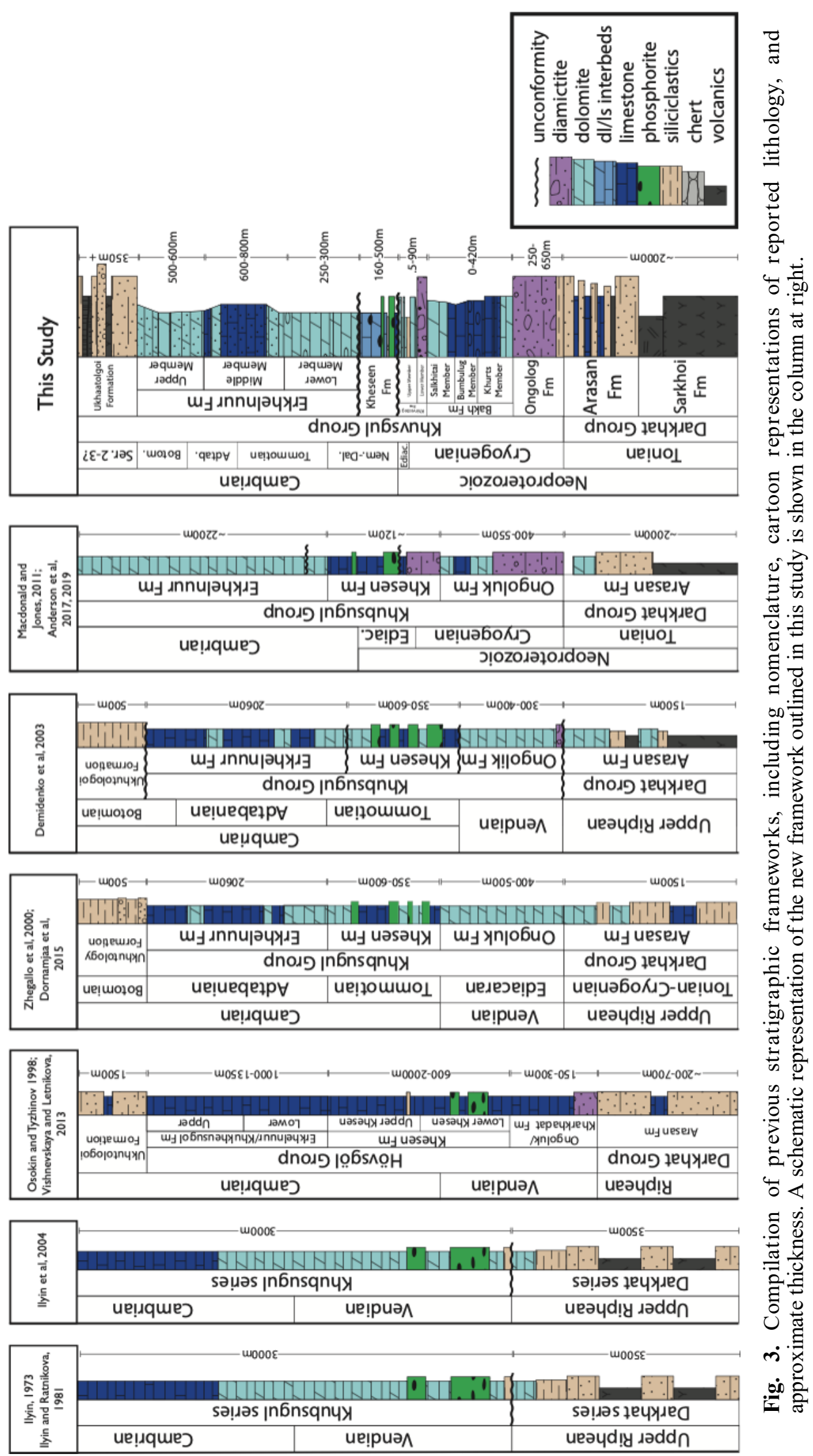


transgressive sequence form the Khirvesteg Formation. The newly-defined Kheseen Formation (spelling adapted to conform to Mongolian anglicized spelling standardization) includes the Khuvsgul phosphorite and overlying carbonate grainstones and mass-flow deposits. We then define Lower, Middle, and Upper members of the Erkhelnuur Formation based on regional lithostratigraphic trends in order to streamline mapping, field identification, and structural relationships. Finally, varied siliciclastic rocks overlying the Erkhelnuur Formation are incorporated into the Ukhaatolgoi Formation.

\section{METHODS}

During the course of a geological mapping campaign spanning three field seasons (summers of 2017-2019), we measured more than $8,000 \mathrm{~m}$ of stratigraphic section at submeter resolution through Khuvsgul Group exposures in the Khoridol Saridag Range and Darkhat Valley. Section locations are depicted in Fig. 2, while representative stratotype sections are plotted in Fig. 5. By combining our lithostratigraphic and facies observations (both from measured sections and from outcrop encountered during the course of geologic mapping) with structural relationships from our mapping efforts, we discretized constituent formations of the Khuvsgul Group into a stratigraphic framework that will streamline future work in the region. Formalized unit names, type section locations, thicknesses, age constraints, and correlations are summarized in Table 1.

\section{Ongolog Formation}

\section{Stratigraphy}

Composed of poorly sorted sandstone, siltstone, conglomerate, and diamictite, the Ongolog Formation is $250-650 \mathrm{~m}$ thick, with changes in both thickness and facies observed in northsouth along-strike exposures west of Lake Khuvsgul. The Ongolog Formation is well exposed on the northern slopes of Ongolog Gorge (Fig. 2), with recessive, poorly outcropping clast-free sequences of fine to medium-grained lithic arenites giving way upsection to more resistant matrix-supported stratified diamictite, with the matrix composed of the same material that makes up the clast-free interval below. On a ridge north of Kheseen Gorge (Fig. 2), a continuous section preserves the gradual transition from clast-free siliciclastic material to massive diamictite (see sections M613 and M614 in Macdonald and Jones, 2011). At both localities, the formation culminates in massive, dark-colored, argillite matrix diamcitite with clasts of carbonate, sandstone, and crystalline basement ("perforated shales" of Ilyin, 1973), depicted in in Fig. 4A.

\section{Bakh Formation}

Named for its type locality on a ridgeline above Bakh Gorge (EA1701 and EA1702, Fig. 5), the Bakh (бax; tr. "toad") Formation is composed of platformal and upper slope carbonate sequences that are subdivided into three distinct members.

Khurts Member: Dolomite wackestone and finelaminated grainstone of the lowermost Khurts (хурц; tr. "sharp") Member of the Bakh Formation directly overly the Ongolog Formation, with a sharp, conformable or paraconformable contact. Although most Khurts Member exposures are heavily recrystallized, a generally shallowing-upward trend is suggested by the increase of coarse grainstone and grainflow deposits containing ooids and microbial mat rip-up clasts towards the top of the member. The Khurts Member is $20-120 \mathrm{~m}$ thick, and thickens to the southwest.

Bumbulug Member: A conformable transition to repeating shallowing-upward parasequences of limestone mudstone, marl (mixed carbonate and fine-graded siliciclastic rocks), and rhythmite (graded calcisiltite to micrite) interbeds marks the beginning of the Bumbulug (бөмбөлөг; tr. "bubbly") Member. Vitreous black-grey ellipsoidal chert nodules from $1-3 \mathrm{~cm}$ are distributed throughout thicker, tawny-brown mudstone beds, giving outcrops a bubbly, almost sponge-like appearance. Thinner laminated mudstone, marl, and rhythmite are more frequent up-section, with $\mathrm{mm}$ - to $\mathrm{cm}$-scale bedded chert interspersed throughout; the Bumbulug Member is 50-150 m thick. 
Table 1. Formalization of newly defined stratigraphic units of the Khuvsgul Group

\begin{tabular}{|c|c|}
\hline Name & Ongolog Formation \\
\hline Name Derivation & $\begin{array}{l}\text { Good, albeit incomplete, exposures in and around Ongolog Gorge, Khuvsgul Aimag. Mongolia; previously used as the name for a broade } \\
\text { formation that included the now-differentiated Ongolog and B akh Formations }\end{array}$ \\
\hline Category and Rank & Lithostratigraphic Formation \\
\hline Type Area & South-facing slopes north of Kheseen Gorge, K huvsgul A imag, Mongolia \\
\hline Unit Type Section & $\begin{array}{l}\text { Composite section M613 and M614 (Macdonald and Jones, 2011; Fig. 2, this paper). South-facing slope near top of ridge/treeline north of } \\
\text { Kheseen Gorge; near northeasternmost exploratory trench visible on satellite imagery. Gradational basal contact begins just west of section start } \\
(50.74887 \mathrm{~N}, 100.19923 \mathrm{E}) \text {, ends just below first exposure of allodapic limestones to WNW }\end{array}$ \\
\hline Unit Description & $\begin{array}{l}\text { Poorly sorted litharenites, silts, and gritty lags grade into matrix supported, beige-green to purple-weathering matrix-supported diami ctite hosting } \\
\text { sub angular to subrounded clasts (dominantly carbonates, with minor quartzite and granitic clasts) ranging from pebbles to boulders. Reported } \\
\text { striated and faceted clasts (Osokin and Tyzhinov, 1998) suggest a glacigenic origin. Massive and stratified diamictite facies present in varying } \\
\text { abundance throughout exposures, with rapid facies and thickness variability apparent between along-strike exposures at sub-km length scales. } \\
\text { Uppermost strata of the Ongolog Formation include a massive diamictite with sub-rounded to sub angular carbonate, granite, and quartzite clasts } \\
\text { supported by a dark grey argillitic matrix }\end{array}$ \\
\hline $\begin{array}{l}\text { Unit Reference } \\
\text { Sections }\end{array}$ & $\begin{array}{l}\text { 1. M605 (50.710609N, } 100.178601 \mathrm{E}) 2 . \mathrm{M} 610(50.72995 \mathrm{~N}, 100.18197 \mathrm{E}) \text { (Macdonald and Jones, 2011), located in Ongolog Gol and on ridge } \\
\text { north of Ongolog Gol, respectively }\end{array}$ \\
\hline Dimensions & $\sim 430 \mathrm{~m}$ in composite type section, estimated thicknesses from $\sim 250 \mathrm{~m}$ in Ongolog Gorge to up to $650 \mathrm{~m}$ to north \\
\hline Geologic Age & Earliest Cryogenian $(\sim 719 \mathrm{Ma})$ to end-Sturtian $(\sim 660 \mathrm{Ma})$ via correlation with globally distributed Sturtian glacial diamicti tes \\
\hline Regional Correlations & Maikhan-Uul Fm, Zavkhan Terrane, Mongolia (Macdonald and Jones, 2011, B old et al., 2016a) \\
\hline Name & Balh Formation (Khurts, Bumbulug, and Salkhitai Members) \\
\hline Name Derivation & $\begin{array}{l}\text { Type section located on ridge west of Bakh Gorge, Khuvsgul Aimag, Mongolia, with best access by foot up Bakh Gol. Khurts (xypц; } t r \text {. } \\
\text { "sharp") Member is often a cliff-forming unit; B umbulug (бөмбөлег; } t r \text {." "bubbly") Member contains nodular cherts that are remini scent of } \\
\text { bubbles on exposed weathered surfaces; Salkhitai (салхит ай; } t r \text {. "winch") Member is often a ridge-forming unit, with a stratotype section on a } \\
\text { ridgeline that is particularly exposed to wind and weather }\end{array}$ \\
\hline Category and Rank & Lithostratigraphic Formation composed of 3 component Members \\
\hline Type Area & Ridge on the westernmost rim of the upper northern drainage area of Bakh Gorge, Khuvsgul Aimag, Mongolia \\
\hline Unit Type Section & $\begin{array}{l}\text { EA1701-2 (Figures } 2 \text { and 5, this paper). Lower Boundary. lowest continuous exposure of Khurts Member (50.87971N, 100.17848E) above } \\
\text { nearby Ongolog Formation outcrop. Section follows exposures al ong the northern and eastern edges of ridge crests. Upper Boundary. contact } \\
\text { with overlying yellow carbonate diamictite of Khirvesteg Formation }(50.875802 \mathrm{~N}, 100.179634 \mathrm{E})\end{array}$ \\
\hline \multirow{3}{*}{ Unit Description } & $\begin{array}{l}\text { Khurts Member: dolomite wackestones and laminated grainstones, often heavily recrystallized to the point of destroying primary sedimentary } \\
\text { textures. Generally appears to shallow up section: ooids and microbial textures more frequent towards top of member }\end{array}$ \\
\hline & $\begin{array}{l}\text { Bombolog Member: shall owing-upward parasequences of limestone, mudstone, and marl. Ellipsoi dal chert nodules }(1-3 \mathrm{~cm}) \text { throughout thi cker } \\
\text { mudstone beds; laminated mudstones, marls, rythmites, and bedded mm-scale cherts become frequent upsection }\end{array}$ \\
\hline & $\begin{array}{l}\text { Salkhitai Member: coarse limestone grainstone parasequences, grading into thi cker dolomitized grainstones, grainflow deposits, carbonate } \\
\text { intraclast breccias, and sedimentary breccias often with lithic grains in matrix material }\end{array}$ \\
\hline $\begin{array}{l}\text { Unit Reference } \\
\text { Sections }\end{array}$ & $\begin{array}{l}\text { 1. } 40 \mathrm{minto} \text { EA1 } 1814 \text { ( } 50.85318 \mathrm{~N}, 100.06865 \mathrm{E}) \text {, Arsai Gorge (Figures } 2 \text { and 5, this paper) 2. partial exposures in Khe seen and Ongolog Gorges } \\
\text { (Fig. 2, this paper) }\end{array}$ \\
\hline Dimensions & $\begin{array}{l}\text { At the type section, the Khurts Member is at least } 20 \mathrm{~m} \text { thick, the Bombolog Member is } \sim 120 \mathrm{~m} \text { thick, and the Salkhitai Member is } \sim 175 \mathrm{~m} \text { thick. } \\
\text { Elsewhere in the basin, the Khurts, Bombolog, and Salkhitai Members have been estimated to be a maximum of } 120 \mathrm{~m}, 150 \mathrm{~m} \text {, and } 175 \mathrm{~m} \text { thick } \\
\text { respectively, both at EA1814 and at incomplete exposures in the easternmost Khoridol-Saridag Range }\end{array}$ \\
\hline Geologic Age & Cryogenian non-gl acial interlude; $>660 \mathrm{Ma}$ to likely younger than $\sim 657 \mathrm{Ma}$ (Rooney et al., 2020 ) \\
\hline Regional Correlations & Taishir Fm, Zavkhan Terrane, Mongolia (Macdonald and Jones, 2011; Bold et al., 2016a) \\
\hline Name & Khirvesteg Formation \\
\hline Name Derivation & Good exposure in outcrop on the south-facing hillsides west of Khirvesteg Gorge, Khuvsgul Aimag, Mongolia \\
\hline Category and Rank & Lithostratigraphic Formation \\
\hline Type Area & Ridge on the westernmost rim of the upper northern drainage area of Bakh Gorge \\
\hline Unit Type Section & $\begin{array}{l}\sim 300 \mathrm{~m} \text { into EA } 1701-2(50.875683 \mathrm{~N}, 100.179771 \mathrm{E}), \text { Bakh Gorge ridge (Figures } 2 \text { and } 5 \text {, this paper). Lower Boundary: locally conformable } \\
\text { contact with underlying dolomite grainstone of Salkhitai Member, Bakh Formation ( } 50.875802 \mathrm{~N}, 100.179634 \mathrm{E}) \text {. Section continues through } \\
\text { outcrop exposure on northern edge of ridgeline. Upper Boundary: unconformity surface at contact with Kheseen Formation ( } 50.875516 \mathrm{~N} \text {, } \\
100.179958 \mathrm{E})\end{array}$ \\
\hline Unit Description & $\begin{array}{l}\text { Yellow-weathering massive matrix-supported diamictite, containing angular to sub-angular carbonate clasts in a dolomite matrix Often } \\
\text { interfingered with angular dolomite boulder breccias; thickness of diamictite/breccia package highly variable in along-strike exposures. The } \\
\text { diamictite is overlain by a } 3 \mathrm{~m} \text { thick, cream-colored dolomite grainstone, often bearing sheetcrack cements and barite fans., interpreted to be a cap } \\
\text { carbonate paired with the underlying diamictite. Above the cap carbonate, a transgressive sequence of marls, mudstones, and thinly laminated } \\
\text { carbonaceous shales, ranging in color from white to tawny brown on weathered surfaces, is found at most exposures }\end{array}$ \\
\hline Unit Reference & 1. M611 (50.692094N, 100.172123E), K hirvesteg Gorge, (Macdonald and Jones, 2011). 2. M607-M609 composite section (50.691558N, \\
\hline Sections & 100.171421E), northern Ongolog Gorge. 3. 200m into EA1814 (50.85510N, $100.06526 \mathrm{E})$, Arsai Gorge (Figures 2 and 5 , this paper) \\
\hline Dimensions & $\begin{array}{l}\text { At the type section, the diamictite/dolomite breccia unit is } \sim 25 \mathrm{~m} \text { thick, the Marinoan cap is } \sim 3 \mathrm{~m} \text { thick, and the overlying Ediacaran strata are } \\
\sim 20 \mathrm{~m} \text { thick. Diamictites at Reference Section } 2 \text { approach } 50 \mathrm{~m} \text { in thickness, with a } \sim 2 \mathrm{~m} \text { thick cap carbonate sequence and nearly } 50 \mathrm{~m} \text { of overlying } \\
\text { Ediacaran strata. A round the basin, thi cknesses range from } 0.5 \text { to } \sim 70 \mathrm{~m} \text { for the Khirvesteg diami ctite, } 1-3 \mathrm{~m} \text { for the Marinoan cap carbonate, and } 0 \\
\text { to } 50 \mathrm{~m} \text { for the Ediacaran strata }\end{array}$ \\
\hline Geologic Age & Onset of Marinoan Glaciati on (younger than $657 \mathrm{Ma}$; Rooney et al., 2020) to early Edi acaran (younger than 635Ma) \\
\hline Regional Correlations & Khongor Formation and lower O1 Formations, Zavkhan Terrane, Mongolia (Macdonald and Jones, 2011; Bold et al., 2016a) \\
\hline
\end{tabular}


Table 1. Formalization of newly defined stratigraphic units of the Khuvsgul Group (continue)

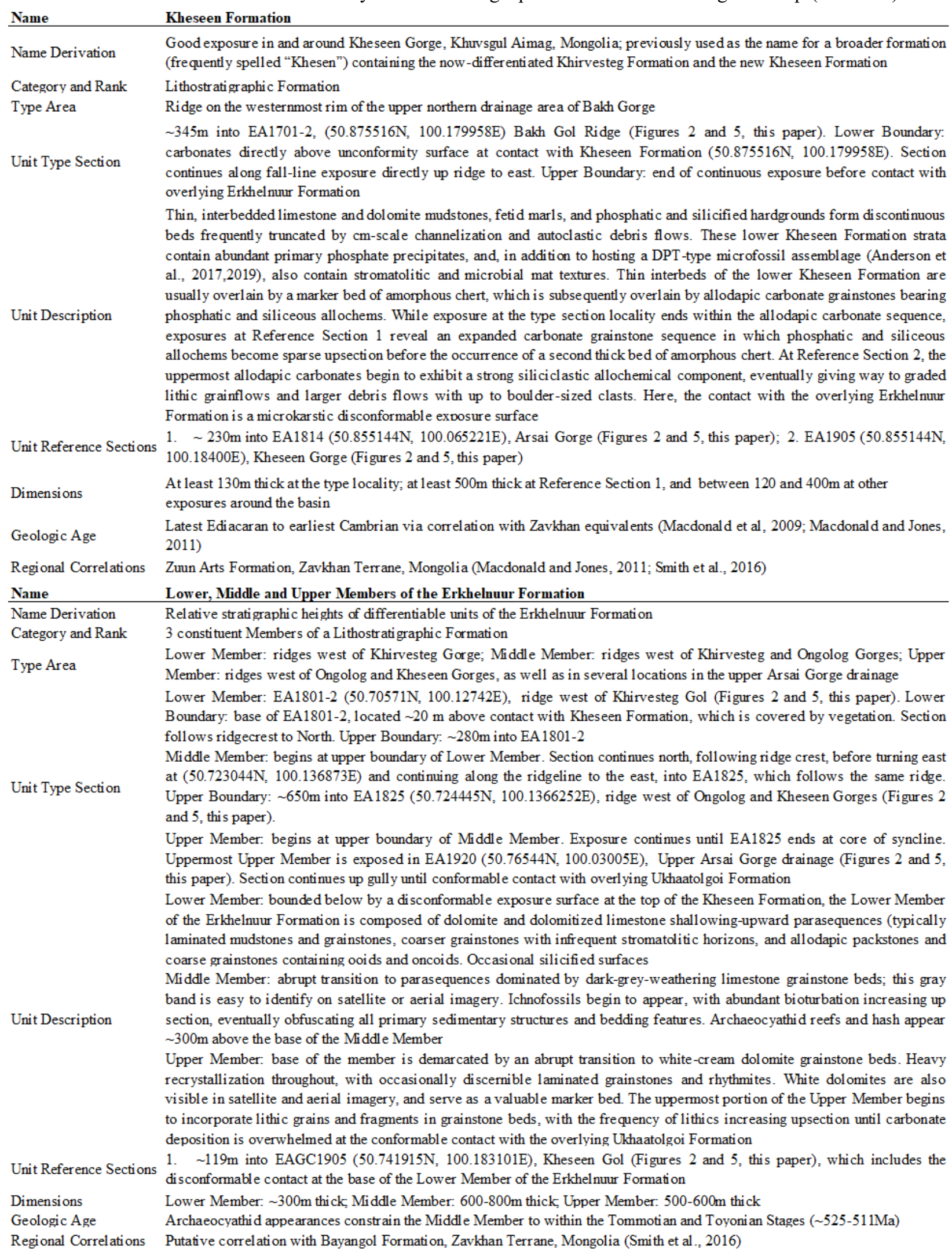


Salkhitai Member: The uppermost portion of the Bakh Formation, the Salkhitai (салхитай; tr. "windy") Member, conformably overlies the Bumbulug Member and contains coarse limestone grainstone-dominated parasequences that transition into a coarsening-upward stack of dolomitized grainstone, grainflow deposits, and intraclast breccia with a minor siliciclastic granular component. The top of the Salkhitai
Member is marked by a coarse, carbonatecemented sandstone with carbonate granules that is overlain by a massive unit of dolomite grainstone. The Salkhitai Member ranges between $100 \mathrm{~m}$ and $150 \mathrm{~m}$ in thickness.

\section{Shar Formation}

The Shar (шар; tr. "yellow") Formation is composed of a massive matrix-supported

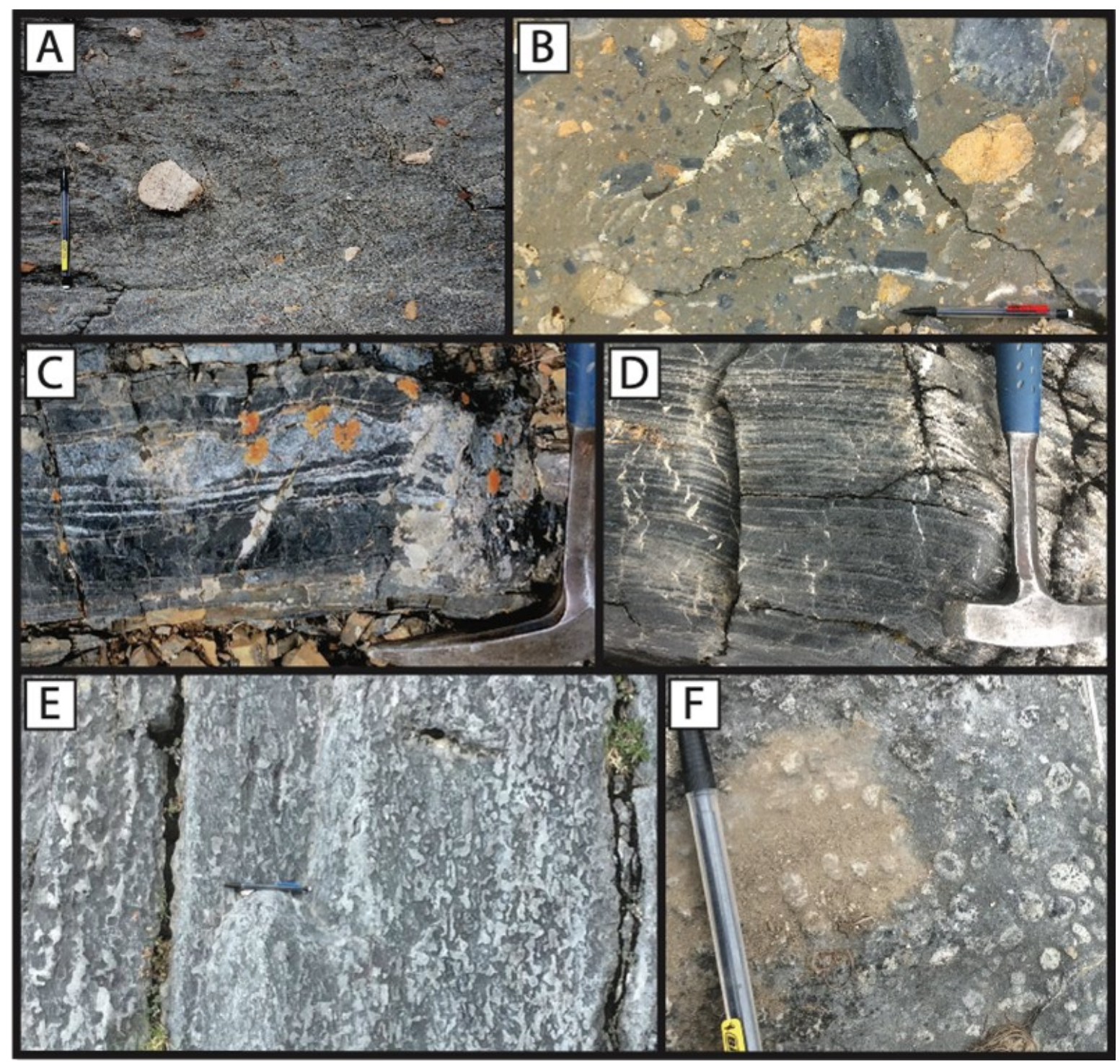

Fig. 4. Khuvsgul Group rocks in outcrop and hand-sample. A: Matrix-supported diamictite of the Ongolog Formation, featuring sub-angular to sub-rounded carbonate and granitic clasts. B: Yellow, dolomite-matrixsupported diamictite of the Shar Formation, with angular to sub-angular carbonate clasts, many of which are lithologically similar to strata of the underlying Bakh Formation. C: phosphorite of the lower phosphatic units of the Kheseen Formation observed in EA1701, with discontinuous layers of primary phosphatic material weathering blue-white between darker chert and limestone beds. D: Dolomite grainstones of the Kheseen Formation bearing phosphatic allochems, EA1814. E: Bed-penetrating bioturbation within grainstones of the Middle Member of the Erkhelnuur Formation. F: Archaeocyathid hash in grainstones of the Middle Member of the Erkhelnuur Formation. 
diamictite with a distinctive yellow-ochre dolomite matrix (Fig. 4B), often closely associated with coarse, gray-weathering angular dolomite breccia. Around the basin, thickness of diamictite-breccia packages ranges from 0.5-70 $\mathrm{m}$. The base of the member is defined as the transition from dolomite grainstone of the uppermost Bakh Formation to diamictite or dolomite breccia. At the stratotype locality above Bakh Gorge, the Shar Formation is approximately $20 \mathrm{~m}$ thick, with nearly ten meters of angular dolomite breccia overlain by the eponymous yellow diamictite (EA1701-2, Fig. 5).

\section{Khirvesteg Formation}

Conformably above the diamictite and breccia, the base of the Khirvesteg Formation is defined by a 1-3 $\mathrm{m}$ thick dolomite grainstone containing barite fans and sheetcrack cements (Hoffman et al., 2011). The cap carbonate is overlain by thin dolomitic marl, mudstone, and carbonaceous shale. Although exposures to the south are locally only $2-3 \mathrm{~m}$ thick, $25 \mathrm{~m}$ of marl, shale, and dolomite mudstone are found in the stratotype section on the ridge above Bakh Gorge (EA1701-2, Fig. 5). Note that in Fig. 2, the Shar and Khirvesteg Formations are shown as a single map unit for visual clarity at the presented map scale.

\section{Kheseen Formation}

Ranging from 160-500 $\mathrm{m}$ in thickness, the Kheseen Formation is separated from the Khirvesteg Formation by a prominent erosional unconformity. Above this surface, the basal Kheseen Formation is composed of interbedded black micritic limestone and dolomite mudstone, foetid marl and shale, and phosphatic and silicified hardgrounds (Fig. 4C). Bedding is largely discontinuous along strike, and is often truncated by channelization or autoclastic debris flows, while thicker carbonate beds contain stromatolitic and thrombolitic textures. Phosphatic hardgrounds and phosphatic grainflows in these strata contain a DoushantuoPertatanka-Type microfossil assemblage, described by Anderson et al. (2017; 2019). This sequence, referred to in previous works as the lower phosphate unit (Ilyin and Ratnikova,
1981; Ilyin, 1998), is 10-60 $\mathrm{m}$ thick, and contains the most concentrated phosphate ore (average of $22 \%$ and up to $34 \% \quad \mathrm{P}_{2} \mathrm{O}_{5}$; Dorjnamjaa and Altanshagai, 2015) in the region. This phosphatic unit is capped by $1-5 \mathrm{~m}$ of massive amorphous black chert. Above this, granular phosphorite is present in graded allodapic limestone and dolomite grainstone (Fig. 4D). This facies forms the majority of phosphorite exposure in the Khuvsgul Basin. In the Western Khoridol Saridag Range (KSR), the Kheseen Formation is capped by a second chert bed, whereas in the easternmost KSR it is composed of grainstone and coarse conglomerate with a large siliciclastic component not observed elsewhere in the basin. The stratotype section for the Upper Kheseen Formation is on the ridge above Bakh Gorge (EA1701-2) with reference sections in Arsai Gorge (EA1814), which includes an expanded upper phosphorite sequence, and in Ongolog Gorge (EA1905), which contains conglomerate with abundant lithic clasts at the top of the formation. All sections are depicted in Fig 5.

\section{Erkhelnuur Formation}

The Erkhelnuur Formation (Zhegallo, 2000) is a $2 \mathrm{~km}$ thick carbonate sequence separated from the Kheseen Formation by a hiatal surface, observed in the Eastern KSR (EA1905) as a disconformable exposure surface, with the base of the Erkhelnuur Formation defined as the carbonate grainstones overlying this surface. In order to simplify structural interpretation and lithological differentiation of Erkhelnuur Formation carbonates in the field, we propose the subdivision of the formation into Lower, Middle, and Upper Members, which are summarized below.

Lower Member: The Lower Member includes repetitive dolomite and dolomitized limestone parasequences, composed of laminated mudstone and grainstone interbeds, dolomitized grainstone beds containing domal stromatolites, and allodapic packstone and coarse grainstone containing ooids and oncoids. Parasequences are commonly capped by horizons of lenticular grey -black chert. The Lower Member is 250-300 m 


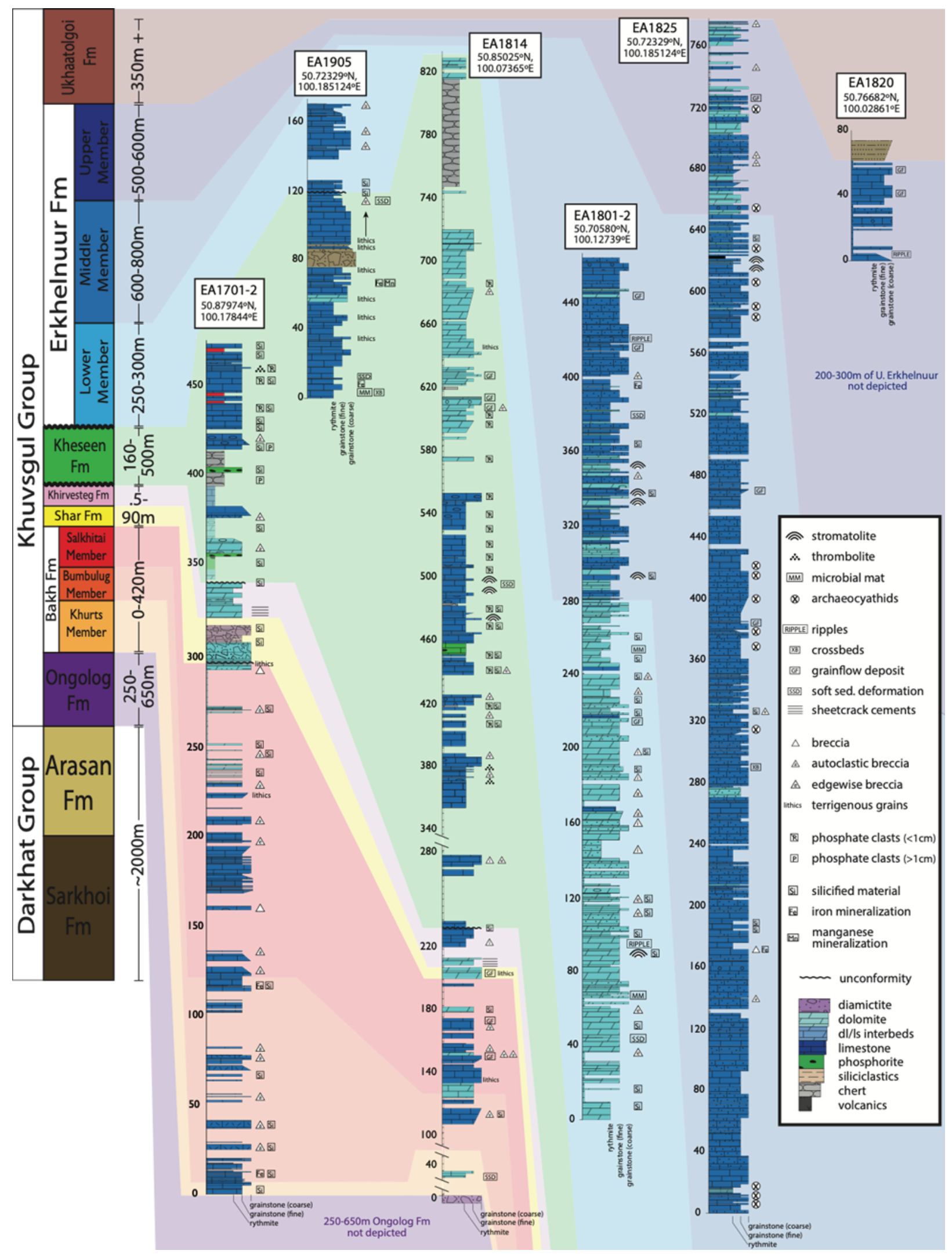

Fig. 5. Measured stratigraphic sections from Khuvsgul Group type-localities. All section locations are depicted in Fig. 2, while coordinate locations shown above are from the stratigraphic base of each section. 
thick, with a stratotype exposure on a ridge above Khirvesteg Gorge (EA1801-2, Fig. 5).

Middle Member: The base of the Middle Member of the Erkhelnuur Formation is defined by an abrupt transition to parasequences dominated by dark grey limestone grainstone beds. While the parasequences include stromatolitic mudstone and dolo-rhythmite, this transition is visible both in the field and on satellite imagery, where limestone-dominated parasequences appear as a dark blue-gray band. In most sections, bed-penetrating ichnofossils appear 20-50 $\mathrm{m}$ above the base of the Middle Member, consisting of irregular 1-2 cm diameter tubes. The density of bioturbation increases up-section to the point of obfuscating primary bedding features (Fig. 4E). Approximately $300 \mathrm{~m}$ above the base of the Middle Member, archaeocyathid reefs and hash can be observed in bioturbation-free zones (Fig. $4 \mathrm{~F}$ ), constraining the strata to a window of the early Cambrian between the Tommotian and Toyonian Stages ( 525-511 Ma, or midTerreneuvian Age 2 to Cambrian Series 2, Age 4; Peng et al., 2020). The Middle Member of the Erkhelnuur Formation ranges from 600-800 m thick, and is best exposed in sections EA18011802 (see Fig. 5) on the ridges above Khirvesteg Gorge.

Upper Member: The base of the Upper Member of the Erkhelnuur Formation is demarcated by a sequence of $>50 \mathrm{~m}$ thick white- to creamcolored dolomite grainstone beds. Although the white beds locally preserve laminated grainstone and rhythmite, in most exposures, primary bedding features are obliterated by recrystallization. Like the dark beds at the base of the Middle Member, the basal white dolomite of the Upper Member forms a reliable marker bed that is easily visible in the field and satellite imagery. Above the white dolomite, grey dolomite and limestone laminite-grainstonegrainflow parasequences continue, with ichnofossils present in fine grainstone beds. Upsection, coarser-grained grainstone and grainflows incorporate terrigenous lithic fragments, which increase in frequency and size toward the top of the section. The Upper
Member is $500-600 \mathrm{~m}$ thick; the base of the Member is best exposed in EA1825, while the uppermost grainflows are prominently exposed in section EA1820 (Fig. 5).

\section{Ukhaatolgoi Formation}

The $>350 \mathrm{~m}$ thick Ukhaatolgoi Formation conformably overlies the Erkhelnuur Formation and is composed of siliciclastic rocks dominated by greywacke with minor siltstone, sandstone, and conglomerate. Carbonate parasequences of the uppermost Erkhelnuur Formation contain allochems that are gradationally succeeded by greywacke of the basal Ukhaatolgoi Formation. Previously referred to as the Ukhutologoy Formation (Zhegallo et al., 2000; Demidenko et al., 2003) and excluded from the Khuvsgul Group, the Ukhaatolgoi Formation is dominated by green greywacke, with rare granule to pebble lithic clasts, angular quartz and plagioclase grains, and carbonate fragments in a green siltstone matrix. The base of the formation is best documented in section EA1820, and the formation is best exposed at the cores of synclines in upper Arsai Gorge. Note that we do not include the formalization of this Formation in Table 1, as this nomenclature has been applied to these rocks by previous workers (Dorjnamjaa et al., 2015).

\section{DISCUSSION}

While the stratigraphic divisions outlined above are largely based on lithological characteristics that can be easily differentiated in the field by future workers, our stratigraphic framework is also reflective of significant changes in paleoenvironment and paleoclimate that occurred during the deposition of the Khuvsgul Group. For example, the Ongolog, Bakh, Shar, and Khirvesteg formations can be correlated with the Sturtian glaciation, Cryogenian nonglacial interlude, Marinoan Glaciation, and basal Ediacaran transgression respectively, with diamictites associated with both glaciations separated by a platformal carbonate sequence (Macdonald and Jones, 2011). A glaciogenic origin for the Ongolog Formatiton is established via the observation of exotic clasts in matrixsupported diamictite, as well as striated and faceted clasts (Osokin and Tyzhinov, 1998). 
Typically exhibiting sheetcrack cements and crystal fans, the basal carbonate of the Khirvesteg Formation is interpreted as a cap carbonate sequence (Hoffman et al., 2011), coupled with the underlying diamictite of the Shar Formation. Additionally, these units can be correlated with Cryogenian and Ediacaran successions on the Zavkhan Terrane in southwest Mongolia (Macdonald and Jones, 2011; Bold et al., 2016b).

Bound above and below by unconformities, the newly-defined Kheseen Formation records a depositional environment that resulted in the precipitation and eventual reworking of the Kheseen phosphorites, which may be condensed equivalents of the phosphatic shales of the Zuun Arts Formation on the Zavkhan Terrane (Macdonald and Jones, 2011). The lower units of the Kheseen Formation record precipitation of primary phosphatic material in a very shallow, energetic depozone, whereas phosphatic material in the upper parts of the formation has been redeposited in carbonate grainstones (Fig. 5). Importantly, the newly defined lower bound of the Kheseen Formation isolates the phosphatic strata from the underlying Khirvesteg and Shar formations, highlighting the lack of a previously-postulated genetic relationship between the Marinoan glaciation and phosphogenesis (Osokin and Tyzhinov, 1998). Furthermore, the disconformable exposure surface at the top of the formation separates the Kheseen Formation in time from the nearly $2 \mathrm{~km}$ of overlying Erkhelnuur Formation carbonates, introducing the possibility that the Kheseen and Erkhelnuur formations were accommodated by distinct basin-forming events. Additional petrographic, geochronological and chemostratigraphic data are necessary to better constrain the ages and depositional environments of the Kheseen phosphorites and Khuvsgul Group strata as a whole. The stratigraphic framework presented here provides a necessary foundation for future work in the Khuvsgul region.

\section{CONCLUSIONS}

A new stratigraphic framework for the Khuvsgul Group divides strata spanning nearly 200 My of Earth history into seven formations.
Cryogenian strata are divided into the Ongolog, Bakh, Shar, and Khirvesteg formations, discretizing units associated with the Sturtian glaciation, Cryogenian non-glacial interlude, Marinoan Glaciation, and basal Ediacaran transgression respectively. Phosphatic strata, bounded above and below by depositional hiatuses, are included in the newly defined Kheseen Formation. In order to streamline mapping and correlation, the Erkhelnuur Formation is divided into Lower, Middle, and Upper Members, while the overlying siliciclastic sequences are discretized as the Ukhaatolgoi Formation.

\section{ACKNOWLEDGEMENTS}

Thanks to Erdene Bayarsaikhan, Ekv Erdene, Sam Lobianco, Peter Otness, and Judy $\mathrm{Pu}$ for assistance, companionship, and camaraderie in the field, to M. Munkhbaatar, Batsukh Erdene, and Set for transportation and friendship, to Ariunsanaa Dorj and the Earth Science Center of Mongolia for logistic help, and to the Ministry of Environment of Mongolia and the rangers and staff of the Khuvsgul Nuur National Park and Khoridol Saridag Protected Zone for access. This work was funded by grant funds from Nasa Astrobiology: Exobiology and Evolutionary Biology, NNH10ZDA001N-EXO and the NSFGRFP.

\section{REFERENCES}

Anderson, R.P., Macdonald, F.A., Jones, D.S., McMahon, S., Briggs, D.E. 2017. Doushantuo -type microfossils from latest Ediacaran phosphorites of northern Mongolia: Geology, v. 45(12), p. 1079-1082. https://doi.org/10.1130/G39576.1

Anderson, R.P., McMahon, S., Macdonald, F.A., Jones, D.S. Briggs, D.E. 2019. Palaeobiology of latest Ediacaran phosphorites from the upper Khesen Formation, Khuvsgul Group, northern Mongolia: Journal of Systematic Palaeontology, v. 17(6), p. 501-532. https://doi.org/10.1080/14772019.2018.1443977

Bold, U., Smith, E.F., Rooney, A.D., Bowring, S.A., Buchwaldt, R., Dudás, F.Ö., Ramezani, J., Crowley, J.L., Schrag, D.P., Macdonald, F.A. 2016a. Neoproterozoic stratigraphy of 
the Zavkhan terrane of Mongolia: The backbone for Cryogenian and early Ediacaran chemostratigraphic records: American Journal of Science, v. 316(1), p. 1-63. https://doi.org/10.2475/01.2016.01

Bold, U., Crowley, J.L., Smith, E.F., Sambuu, O., Macdonald, F.A. 2016b. Neoproterozoic to early Paleozoic tectonic evolution of the Zavkhan terrane of Mongolia: Implications for continental growth in the Central Asian orogenic belt: Lithosphere, v. 8(6), p. 729750. https://doi.org/10.1130/L549.1

Bold, U., Isozaki, Y., Aoki, S., Sakata, S., Ishikawa, A., Sawaki, Y., Sawada, H. 2019. Precambrian basement, provenance implication, and tectonic evolution of the Gargan block of the Tuva-Mongolia terranes, Central Asian Orogenic Belt: Gondwana Research, v. 75, p. 172-183. https://doi.org/10.1016/j.gr.2019.05.003

Demidenko, Y.E., Zhegallo, E.A., Parkhaev, P.Y., Shuvalova, Y.V. 2003. Age of phosphorites from the Khubsugul basin (Mongolia): Dolkady Earth Sciences $\mathrm{C} / \mathrm{C}$ of Dolkady Akademiia Nauk, v. 389, p. 317-321.

Dorjnamjaa, D., Altanshagai, G. 2015. Concerning the original viewpoint of biogeologic accumulation of the old bedded phosphorites in the Khubsugul and Zavkhan basins of Mongolia: Open Journal of Geology, v. 5(09), p 666. https://doi.org/10.4236/ojg.2015.59059

Dorjnamjaa, D., Enkhbaatar, B., Altanshagai, G. 2015. Concerning Precambrian and Cambrian regional stratigraphy of Mongolia: Mongolian Geoscientist, v. 42, p.2-11.

Hoffman, P.F., Macdonald, F.A., Halverson, G.P. 2011. Chemical sediments associated with Neoproterozoic glaciation: iron formation, cap carbonate, barite and phosphorite: Geological Society, London, Memoirs, v. 36(1), p.67-80. https://doi.org/10.1144/M36.5

Ilyin, A.V. 1971. About the Tuva-Mongolian massif: Materials about the Regional Geology of Africa and Asia: Zarubezhgeologiya, v. 22, p.67-73.

Ilyin, A.V. 1973. Khubsugul phosphoritebearing basin: Moscow, Geolgicheskiy Institut, Doklady Akademiya Nauk SSSR, p. 167 (in Russian).
Ilyin, A.V. 1998. Rare-earth geochemistry of old phosphorites and probability of syngenetic precipitation and accumulation of phosphate: Chemical Geology, v. 144(3-4), p. 243-256. https://doi.org/10.1016/S0009-2541(97)00134-4

Ilyin, A.V., Ratnikova, G.I. 1981. Primary, bedded, structureless phosphorite of the Khubsugul Basin, Mongolia: Journal of Sedimentary Research, v. 51(4), p. 12151222. https://doi.org/10.1306/212F7E69-2B2411D7-8648000102C1865D

Kuzmichev, A.B., Bibikova, E.V., Zhuravlev, D.Z. 2001. Neoproterozoic $(\square 800 \quad \mathrm{Ma})$ orogeny in the Tuva-Mongolia Massif (Siberia): island arc-continent collision at the northeast Rodinia mar-gin: Precambrian Research, v. 110(1-4), p. 109-126. https://doi.org/10.1016/S0301-9268(01)00183-8

Kuzmichev, A.B. 2015. Neoproterozoic accretion of the Tuva-Mongolian massif, one of the Precambrian terranes in the Central Asian Orogenic Belt: The Central Asian Orogenic Belt, p. 66-92.

Macdonald, F.A., Jones, D.S. 2011. The Khubsugul Group, northern Mongolia: Geological Society, London, Memoirs, v. 36 (1), p. 339-345. https://doi.org/10.1144/M36.30

Osokin, P.V., Tyzhinov, A.V. 1998. Precambrian tilloids of the Oka-Khubsugul phosphorite-bearing basin (eastern Sayany, northwestern Mongolia): Lithology and Mineral Resources, $\mathrm{C} / \mathrm{C}$ of Litologiia I Polezyne Iskopaemye, v. 33, p. 142-154.

Peng, S.C., Babcock, L.E., Ahlberg, P. 2020. The Cambrian period in Geologic Time Scale 2020, Elsevier, p. 565-629. https:// doi.org/10.1016/B978-0-12-824360-2.00019-X

Smith, E.F., Macdonald, F.A., Petach, T.A., Bold, U., Schrag, D.P. 2016. Integrated stratigraphic, geochemical, and paleontological late Ediacaran to early Cambrian records from southwestern Mongolia: GSA Bulletin, v. 128(3-4), p.442468. https://doi.org/10.1130/B31248.1

Vishnevskaya, I.A., Letnikova, E.F. 2013. Chemostratigraphy of the Vendian-Cambrian carbonate sedimentary cover of the TuvaMongolian microcontinent: Russian Geology and Geophysics, v. 54(6), p. 567-586. https://doi.org/10.1016/j.rgg.2013.04.008 
Zhegallo, E.A., Rozanov, A.Y., Ushatinskaya G.T., Hoover, R.B., Gerasimenko, L.M., Ragozina, A.L. 2000. Atlas of microorganisms from ancient phosphorites of Khubsugul (Mongolia): Huntsville, AL, National Aeronautics and Space Administration, Marshall Space Flight Center, $166 \mathrm{p}$. 